\title{
The Genus Nyctimystes (Anura: Hylidae) in Australia
}

\author{
G.V. CZECHURA ${ }^{1}$, G.J. INGRAM ${ }^{1}$ and D.S. LIEM ${ }^{2}$ \\ 1 Queensland Museum, \\ P.O. Box 300, South Brisbane, Qld 4101. \\ 2 Micronesian Research Institute, \\ 7104 Blanchard Drive, Derwood, Maryland, 20855, U.S.A.
}

\begin{abstract}
Three species of hylid frogs of the genus Nyctimystes have been reported from Australia. With evidence from morphology and field work, we conclude there is only one species. The earliest available name for this taxon is Hyla dayi Günther 1897, the holotype of which is missing. We refer the species to Nyctimystes and, to stabilise the nomenclature, we designate a neotype.
\end{abstract}

Czechura, G.V., G.J. Ingram and D.S. Liem, 1987. The Genus Nyctimystes (Anura: Hylidae) in Australia. Records of the Australian Museum 39(5): 333-338.

Since Tyler (1968), it has been generally accepted that there are three species of Nyctimystes in Australia: N. hosmeri, $N$. tympancryptis and $N$. vestigea (e.g. Barker \& Grigg, 1977; Cogger, 1983; Cogger et al., 1983). Our field observations in northeast Queensland - at the type localities and others - suggested that there was only one Australian species. An examination of a large series of preserved material, including all extant types, confirmed our suspicions: we found continuous variation in all characters previously thought to be diagnostic of the three species.

Measurements are given in millimetres and ratios are expressed as percentages. The following standard abbreviations are used: SV, snout-vent length; HW, width of the head at the broadest part; HL, distance from the tip of the snout to the middle of the head above the angle of the jaws; EN, distance between the external nostril and anterior border of eye; IN, distance between two external nostrils; ED, diameter of the eye between anterior and posterior borders; IO, interorbital width at narrowest part of frontoparietal; TW, tympanum width; TL, tibial length. Description of webbing on hands and feet follows the formula of Schiøtz (1967). Specimens examined are housed in the Australian Museum (AM), Queensland Museum (QM), American Museum of Natural History (AMNH), Rijksmuseum van Natuurlijke Historie (RMNH), and Naturhistorisches Museum, Wien (NHMW).

\section{HISTORY}

The nomenclatural history of the Australian frogs presently assigned to Nyctimystes is complex. There are two separate issues: 1 . the number of species of Nyctimystes, and 2. the identity of Hyla dayi. Günther (1897) described a frog, Hyla dayi, from Bartle Frere Mountains, NE Queensland - the holotype of which has not been located subsequently (Tyler, 1968; Liem, 1974; Duellman, 1977; Cogger et al., 1983). Andersson (1916) described Hyla tympanocryptis from Malanda on the Atherton Tableland near Mt Bartle Frere. Loveridge (1935) and Copland (1957) considered these names to be synonymous but both noted problems with the identity of the name-bearing specimen of Hyla dayi. Even so, they referred specimens to a taxon of that name. Tyler (1964) first noted the presence of the genus Nyctimystes in Australia and described two new species: Nyctimystes hosmeri from Tully Falls on the southern edge of the Atherton Tablelands, and $N$. vestigea from Mt Bartle Frere. (Cogger et al. [1983] gave the name as "vestigia". It was spelt "vestigia" in the header to Tyler's description, but this was obviously a printing error. In the text, and in later papers, Tyler used "vestigea"). Tyler (1968) showed that Hyla tympanocryptis was a Nyctimystes and stated that it was a valid species separable from both $N$. hosmeri and $N$. vestigea. He also noted difficulties with the identity of Hyla dayi. There were differences between the description of the holotype and the frogs 